\title{
STUDENTS' READINESS TO IMPLEMENT INCLUSIVE EDUCATION IN PRESCHOOLS
}

\author{
Ilze Šūmane \\ University of Latvia, Latvia \\ Līga Āboltina \\ University of Latvia, Latvia
}

\begin{abstract}
Inclusive education (also known as inclusion) is an important principle in modern education. However, it is also a great challenge for the whole education system, beginning with the education policy and ending with activities promoting each child's development. Researchers have pointed out that professional teachers are the key to the success of implementing inclusion; therefore, all teacher education programmes have paid close attention not only to topical issues of the specific specialization methodology, but also to topics that form teachers' professional competence in the field of inclusion. In an analysis of research studies on inclusive teachers' professional profiles, it is important to assess the core values and competencies that teachers need to acquire in order to prepare all teachers for work in inclusive education. The aim of the research is to evaluate the future pre-school teachers' attitudes and readiness to implement the principles of inclusion in their teaching. We used the survey and statistical data processing methods in a descriptive empirical study. The study concludes that future pre-school teachers' attitudes are generally positive about the implementation of inclusion into pre-schools; however, a greater understanding of the essence of an inclusive approach is needed in the study process, as most students consider their knowledge and skills to be insufficient.
\end{abstract}

Keywords: inclusive education (inclusion), professional competence of a pre-school teacher, teacher training.

The article has the following parts: title, abstract, keywords, introduction, methods and materials, results and discussion, and conclusions.

Content: the significance of the problem is justified, the introduction defines the aim of the research; the main text provides an overview of previous studies; the research methodology, data analysis, methods, and results are clear; conclusions are drawn. 


\section{Students' Readiness to Implement Inclusive Education in Preschools}

For several decades, education around the world has been experiencing a paradigm shift in education, making inclusion one of the education system's key principles. However, its implementation into educational institutions' practice is still in process. The difficulties are related to the structure of educational institutions, public opinions, educational programmes, as well as teachers' readiness and ability to work by respecting their pupils' diversity. Professional teachers are considered to be the key to successful inclusion; therefore, a lot of attention in teacher training programmes should be paid not only to topical issues of specific specialization and methodology, but also to the development of values, knowledge, and skills that form teachers' professional competence in inclusive education.

In 2012 the European Agency for Special Needs and Inclusive Education developed the Profile of Inclusive Teachers as a guide for the development of initial teacher education programmes. They defined the core values and competencies of all-inclusive teachers as follows:

1) assessing the diversity of learners

2) providing support to all learners

3) working together - cooperation and teamwork is an important work approach for all teachers

4) continuous personal professional development - teaching is a learning activity and teachers are responsible for their lifelong learning (European Agency for Special Needs and Inclusive Education, 2012).

Another approach to teacher preparation for implementing inclusive education identified four key skills that an inclusive teacher needs to acquire, which is partly in line with the above:

1) knowledge about special needs groups

2) skills to diversify the learning process

3) excellent classroom management skills

4) teamwork skills (Allday et al., 2013; Kwona et al., 2017).

We can conclude that the main achievable results in inclusive teacher training are appropriate knowledge about special needs groups, early diagnosis of special needs, knowledge of classroom management strategies, cooperation skills, and readiness for continuous professional development. At the same time, there are specific issues related to knowledge of special needs groups that should be included in teacher training programmes.

However, the most important key to success is teachers' attitudes towards inclusive education. Shani and Hebels (2016), Booth (2010) revealed that a large number of teachers experience dissatisfaction, fear, or anger when dealing with students with special needs in pedagogical 
work. They also indicated a discrepancy between what teachers have declared and the actual situations. Leatherman and Niemeyer (2005) found a direct correlation among prior knowledge, positive attitude, and inclusive education in action. Kwonaa et al. (2017) showed that learning about inclusive education was more valuable, as it was more likely to show teachers' positive attitudes towards inclusive education and to help teachers become more skilled in creating an inclusive learning environment. Sucuoğlu et al. (2014) indicated that special attention should be paid in curricula to creating a more positive attitude towards inclusion in preschool teachers.

Latvia already has about 20 years of experience in teacher education programmes that focus on inclusive education issues, but Rozenfelde's (2016) research, which was conducted in Latvia in 2016, showed that in fact Latvian society has only just begun the path towards having inclusive schools. Over the past 20 years, a number of studies have been conducted on how prospective teachers' understanding of inclusive education is changing. In the period from 2002 to 2012, Tūbele and Vīgante (2014) concluded that there has been a change of attitude towards people with special needs throughout the learning process. The attitude is based on a different level of understanding because knowledge about the nature of disorders has been acquired, which is necessary to help and support teachers (Tūbele \& Vīgante, 2014).

Pre-schools and pre-school education teachers have a special role to play in the implementation of inclusive education because the pre-school education environment is open, it is oriented towards children's diversity, and new public attitudes are formed in it. This environment reinforces the importance of training pre-school education teachers how to implement inclusive education.

Pre-school teacher education programmes take into account the model of an inclusive pre-school education ecosystem developed by the European Agency for Special Needs and Inclusive Education. The model reveals the essence of good quality pre-school inclusive education in five dimensions. Teacher training (initial education of inclusive pre-school teachers) is included in Dimension 5 (external) as a support structure at the regional / national level and influences all ongoing processes within the model (European Agency for Special Needs and Inclusive Education, 2017).

It is necessary to evaluate the experience of teacher trainings at the University of Latvia, as well as the topicalities of the education system in order to improve the content of teacher study programmes, resulting in graduates' higher professional competence in the field of inclusive education. Waitoller and Artiles (2013), in their study about teacher preparation for work in an inclusive education environment, indicated that 
after graduation, teachers must continue trainings on inclusive education as it is an ongoing process that cannot define a final outcome, not even in teacher professionalism.

The aim of the research is to evaluate future pre-school teachers' attitudes and readiness to implement the principles of inclusive education into their future work.

The article analyses the experience and opinions of students of various pre-school teacher study programmes at the University of Latvia on their readiness to implement inclusive education into pre-schools.

\section{Methodology and Materials}

In the descriptive design empirical study uses a survey method for collecting data: questionnaire and processing of data statistics. The survey involved 113 students from a different pre-primary education teacher program. Respondents were introduced to the purpose of the study before the annexation. On site students completed an online questionnaire containing eleven partially closed questions. The resulting data is processed and analysed by a Microsoft Excel program.

The research question was the following: What are the readiness, attitudes, knowledge and skills towards the implementation of the inclusive education approach of current pre-school teaching students?

\section{Results and Discussions}

Based on the study programmes and courses offered by University of Latvia in teacher education, there are study courses that include inclusive or special education components in pre-school teacher training programmes at the university: Special Pedagogy (3 ECTS), Inclusive Education in a Multicultural Society (4,5 ECTS), Basics of Special Pedagogy (3 ECTS), Introduction to Speech Therapy (3 ECTS), Diversity in School Pedagogical Process (3 ECTS), Personality Development in the Process of Socialization (4,5 ECTS), Inclusive Education: Work with Children with Special Needs (3 ECTS). One study programme mostly offers study courses with content on inclusive education in the amount of 6 ECTS

The research base included students who were studying at the first level of the higher professional study programme "Preschool Education Teacher" (73\%) at the University of Latvia. The students of the 2nd (55\%) and 5th (26\%) semesters, i.e., the first- and the third-year students, who also were studying at pre-school educational institutions. Most students (56\%) reported coming into contact with children with special needs in their professional activity and internships. 
During the study process, this tendency could definitely be assessed as an advantage. In the process of mastering the content of the course on unity of theory and practice, the change to the new learning approach was especially actualized, when the construction of the students' new knowledge was formed on the basis of already acquired knowledge, skills, experience, and attitudes or competences in working with children with special needs.

However, $41 \%$ of the students had no contact with children with special needs, neither during the internships nor in their professional activities. In order to promote these students' readiness to implement an inclusive education into pre-schools, they are encouraged to attend seminars and practical classes to solve practical pedagogical problems in heterogeneous group work, which includes different student experiences in working with children with special needs. As practice has shown, based on the solution of the pedagogical problems, the construction of new knowledge provides students with a deeper and more grounded understanding and readiness for the implementation of inclusive education into pre-schools.

$45 \%$ of the respondents indicated that they come into contact with children with speech disorders, while $46 \%$ of the respondents stated they had contact with children with different cultural and linguistic experiences, and $38 \%$ had contact with children with mixed developmental disorders. The mentioned tendencies show that special emphasis should be placed on inclusive education in a multicultural society in course content, namely for speech therapy and inclusion. When teachers work with children with special needs, these components of inclusion or special education need to be integrated into the content and acquisition of other courses.

Forty-six per cent of the student respondents believed that children with special needs should attend special educational institutions or groups. A similar number of respondents (42\%) admitted that only in very rare cases should children with special needs have to attend special educational institutions or groups. Thus, it can be concluded that pre-school teaching students need to strengthen their understanding of the integration of children with special needs into the pre-school pedagogical process in a general preschool institution, and they need to understand the advantages of inclusive pre-school education.

The respondents' attitude towards inclusive education were most influenced by personal experience (80\%), which confirms what has been said before about students' contact with children with developmental disabilities. Personal experience is a stimulus and promotes students' motivation to find out about the problems they will face in daily practice in preschools within their courses.

Unfortunately, according to the results of the survey, $62 \%$ of the students underestimated the general theoretical knowledge gained in the study 
process about inclusive education and working with children with special needs in a pre-school institution of general education. Only one-fifth of the respondents (20\%) rated their knowledge as sufficient, but $15 \%$ rated it as optimal. Similar results were obtained for the acquired skills in working with children with special needs, namely $72 \%$ of students evaluated their skills as insufficient, $15 \%$ as sufficient, and $10 \%$ as optimal. After assessing their readiness to implement the principles of inclusive education into pre-school education, we found that the majority of students (61\%) were aware that they could do it, but still needed to improve their knowledge and skills.

Based on the respondents' answers, we concluded that students are motivated to work with children with developmental disabilities, and they expressed the need to improve their knowledge and skills. This was also confirmed by $90 \%$ of respondents' stating that in the study process they had an interest in learning more about the issues involved in the principles of inclusive education and special education. We can conclude that in the study process, students have learned to take a cognitive interest in issues of the principles of inclusive education and special education. However, in the future, it will be necessary to strengthen the theoretical positions in practical activities on issues of the principles of inclusive education and special education within the framework of general education study courses.

Respondents were asked what they think should be improved in the study process so that at the end of their studies, they would be better prepared to implement inclusive education. They pointed out that it would be necessary to devote a larger part of the study content to the issues of inclusive education. They also mentioned specific topics that should be included in the study content. For example, one student wrote: "Implementation of a differentiated and personalized approach into practice, topics on identification of special needs, practice on support system and inclusive education, speech therapy, child psychology, cooperation with parents in an inclusive education approach."

Respondents emphasized the need to strengthen their emotional (psychological) readiness during their studies to be able to work at an inclusive pre-school. A large part of the proposals is related to ensuring the connection between theory and practice. During internships, it would be necessary to perform tasks related to the implementation of inclusive pre-school education, as well as to observe examples of good practice of inclusive pre-school education.

Respondents also indicated that they were ready to increase their professional competence on issues of inclusive education by attending professional teacher development courses. This confirms these students' interest and positive attitude towards inclusive education issues. 
After analysing the research data, we can conclude that future preschool teachers' attitudes are generally positive about the implementation of inclusive education into pre-schools. However, they still need a greater understanding of the essence of an inclusive approach in the study process, as most respondents considered their knowledge and skills to be insufficient.

The content of study programmes can be enriched in order to promote future teachers' knowledge and skills in implementing inclusive education by promoting their readiness to identify children with special needs using various teaching methods and organizational forms and cooperation in a professional team. In order to promote more students' readiness to implement inclusive education, administrators should also use the course of pedagogical practices.

\section{Conclusions}

All children in pre-schools need to be provided with good quality education from their teachers' implementing the principles of inclusive education. In order to achieve this, it is important to strengthen teachers' professional competence for work in inclusive education groups; therefore, in the initial teacher training process, it is important to create study content in which students can acquire necessary knowledge and skills, as well as to promote students' positive attitudes towards inclusive education issues. In teacher training, students' knowledge and skills on inclusive education issues in pre-school should be further strengthened through the unity of theory and practice.

Based on the proportion of the existing number of students to teaching staff, the discussion raises the question of how it will be possible, in practice, to ensure that solutions to individual special needs students' problems are identified.

In the course of further research, it will be necessary to identify teaching students' knowledge, skills, and attitudes about inclusive education issues, after they obtain their pre-school teaching qualifications, in their professional work with children with special needs, emphasizing how the knowledge and skills acquired in studies correlate with pre-school teachers' professional competence when working with children with special needs, thus identifying the necessity for their continuing education.

\section{References}

Allday, R. A., Neilsen-Gatti, S., \& Hudson, T. M. (2013). Preparation for inclusion in teacher education pre-service curricula. Teacher Education and Special Education, 36(4), 298-311. doi:10.1177/0888406413497485 
Booth, T. (2010) Teacher Education for Inclusion: How can we know it is of high quality? Keynote given at the Teacher Education for Inclusion project conference; Zurich, September 2010. Available on request from the Agency Secretariat secretariat@ european-agency.org

European Agency for Development in Special Needs Education. (2012). Profile of Inclusive Teachers.

European Agency for Special Needs and Inclusive Education. (2017). Inclusive Early Childhood Education: New Insights and Tools - Final Summary Report. Eds. M. Kyrizpoulou, M., Bartolo, P., Björck-Åkesson, E., Bellour, \& C. Giné.

Kwona, K-A., Hongb, S-Y., \& Jeonc, H-Y. (2017). Classroom readiness for successful inclusion: teacher factors and preschool children's experience with and attitudes toward peers with disabilities. Journal of Research in Childhood Education, 31(3): 360-378. doi:10.1080/02568543.2017.1309480.

Leatherman, J. M., \& Niemeyer, J. A. (2005). Teachers' attitudes toward inclusion: factors influencing classroom practice. Journal of Early Childhood Teacher Education, 26(1): 23-36.

Rozenfelde, M. (2016). Skolēnu ar speciālajām vajadzïbām iekḷaušanas vispārējās izglīitibas iestādēs atbalsta sistēma. Latvijas Universitāte. Pedagoğijas, psiholoǵijas un mākslas fakultāte [Support System for Promoting the Process of Inclusion of Learners with Special Needs in General Education Institutions].

Shani, M. \& Hebel, O. (2016). Educating towards inclusive education: Assessing a teacher-training program for working with pupils with special educational needs and disabilities (SEND) enrolled in general education schools. International Journal of Special Education, 31(3)p.n3.

Sucuoğlu, B., Bakkaloğlu, H., Karasu, F., Demir, S., \& Akalm, S. (2013). Inclusive preschool teachers: Their attitudes and knowledge about inclusion. International Journal of Early Childhood Special Education, 5(2): 107-128.

Tūbele, S., \& Vīgante, R. (2014). Specialās pedagoǵijas izaicinājumi 21. gadsimtā. Latvijas Zinātnuu Akadēmijas Vēstis, 68, 44-54. English: Challenges of Special Pedagogy in the 21 st century.

Waitoller, F. R., Artiles, A. J. (2013). Decade of professional development research for inclusive education: A critical review and notes for a research programme. Review of Educational Research September 2013, 83(3): 319-356. doi: 10.3102/0034654313483905 